\title{
Understanding the Allocative Efficiency of Cassava Farms in Imo State, Nigeria
}

\author{
Esiobu, Nnaemeka Success \\ Department of Agricultural Economics; \\ Imo State University, Owerri, Nigeria
}

In Nigeria and particularly in Imo State, cassava is one of the mostly cultivated and useful root crop. These crop not only contribute to the share of agriculture in national economy, but possess a great potential and comparative advantage to compete in the liberalized economy. Despite all these potentials of cassava, empirical studies on the allocative efficiencies of cassava farmers in Imo State, have not been fully and systematically documented. On the other hand, most empirical studies on cassava have focused mainly on participation and level of adoption of cassava improved technologies. It is on this backdrop that the study was undertaken. Specifically, the study described the socio-economic characteristics of cassava farmers in the study area and allocative efficiency of cassava farmers in the study area and Multistage random sampling technique was used in the selection of respondents. Sample size comprised ninety (90) cassava farmers. Well structured questionnaire was the main tool for data collection. Data collected were analyzed using descriptive statistical tools, and stochastic frontier production model and cost function. Result show that the mean age was 47.00 years. Greater proportions $(73.33 \%)$ were female. Majority (76.67\%) were married with an average household size of 6 persons. The mean educational level and farming experience were secondary and 28years respectively. Average farm size and annual farm income were 1.42ha and N500,500.00 respectively. Reasonable proportions $(81.11 \%)$ were members of cooperative society. The estimated gamma $(\gamma)$ parameter of stochastic frontier production function showed that about $82.7 \%$ variation in output among cassava farmers in the study area was due to differences in relative efficiency. The return to scale (RtS) was 0.549 in the study area. This indicates a positive decreasing return to scale and that cassava production was in stage II of the production region where resources and production were believed to be efficient. The mean allocative efficiency was 0.860 . The policy implication of these findings is that cassava farmers in the study area were efficient in allocating their resources considering their scope of operation and the limited resources. Result also showed that education, membership of cooperative, extension contact, farming experience and household size were farmers socio-economic characteristics that have a significant influence on their relative efficiencies. Hence, the second hypothesis was rejected. It was recommended that farmers particularly on their own should judiciously pool productive resources together through strengthened and stable cooperative society group as this would enhance their relative efficiencies in cassava production positively in the area. Moreover, effective agricultural policies and programmes should focus on granting farmers improved access to farm credit as these would enable them increase their production efficiencies positively in the area. Government at all levels should identify genuine cassava farmers and grant them easy access to farmland as these would significantly increase their relative efficiencies and standard of living positively in the area.

Keywords: Allocative efficiency; Cassava; stochastic frontier production model; Imo State, Nigeria

DOI: $10.7176 / \mathrm{JESD} / 10-19-09$

Publication date:October $31^{\text {st }} 2019$

\subsection{Background Information}

Allocative (Pricing) Efficiency (AE) refers to the ability of a firm to produce at a given level of output using the cost-minimizing input ratios (Ettah and Angba, 2016). In Nigeria, root and tuber crops such as cassava (Manihot spp.) have a significant place in the economy (International Institute of Tropical Agriculture (IITA) (2016) and Nigeria Bureau of Statistics (NBS) 2016). These crops not only contribute to the share of agriculture in national economy, but possess a great potential and comparative advantage to compete in the liberalized economy (Denen, Ayoola, Alakali, Ater, Sanni, Ngadi, Kok, 2016 and Mohammed and Isgin, 2016). Similarly, cassava is grown by almost every household in Nigeria (Onubuogu, Esiobu, Nwosu, Okereke, 2014) and serves more as a major source of income especially for the increasing rural dwellers (Zamanti and Jaderka, 2016). Cassava is also identified as a promising crop for international trade, as demand for cassava derivatives, e.g. garri (a type of processed cassava), starch and tapioca doubled over the last two decades (Ettah and Angba, 2016). Presently, Nigeria is the world largest producer of cassava with an annual production capacity of 54 million tons of tuberous roots; being almost $19 \%$ of the total world production capacity of 215,344,296 million tons, a third more than Brazil and almost double the production capacity of Thailand and Indonesia respectively (Food and Agricultural Organization (FAO), (2016) and Federal Ministry of Finance (FMF), 2017). As a food crop, cassava has some significant inherent characteristics which make it attractive especially to farmers in Nigeria. Firstly, it is rich in carbohydrates, especially starch, and consequently has multiplicity of end uses (Ettah and Nweze, 2016). Secondly, it is available all the year round, making it preferable to other more seasonal crops such as grains, peas, beans and other crops 
for food security (Emokaro and Oyoboh, 2016) and lastly it is tolerant of low soil fertility and more resistant to drought (Okoye, Abass, Bachwenkizi, Asumugha, Alenkhe, Ranaivoson, Randrianarivelo, Rabemanantsoa and Ralimanana, 2016). Cassava tubers are mostly processed into cassava flour (lafun). Cassava flour is dried and powdered form of cassava, garri is fried granulated form of cassava while fufu is fermented pounded form of cassava) in Nigeria (Oni, 2016). Cassava can also be cooked or eaten, pounded and consumed in its raw form, most especially the sweet variety (Oyewo, Adepoju, Ojo, Oyewo, Atanda, 2016). By implication, cassava has become a regular item in household diets in Nigeria (Lora, Posthumus and Martin, 2016). In a similar vein, cassava potential for industrial utilization is yet to be adequately realized; with 84 percent of cassava production reportedly consumed as food and 16 percent utilized as industrial materials (United Nations Industrial Development Organization and Federal Government of Nigeria (UNIDO and FGN) (2016). One of the ways in which optimal relative efficiencies could be achieved is to improve the productivity of cassava farms in the study area. Farmers will be guided on the inputs to focus on, thereby improving the efficient use of scarce resources in cassava production. However, such information on relative efficiencies of resources use of cassava farmers is lacking in Imo State, Nigeria. A significant and valid contributions have been made by various researchers (Adewuyi, Agbonlahor and Oke, 2013; Onumadu et al., 2014; Riatania, Daryanto, Tambunan and Purwati, 2014; Ogunniyi, 2015; Eze, Ohajianya, Ibeagwa and Ojinnaka, 2015; Adegbite and Adeoye, 2015; Denen et al., 2016; Mohammed and Isgin, 2016; Wudineh and Geta, 2016) at various household level in understanding the concept of either technical, allocative and economic efficiencies of various agricultural enterprise at various household level in Nigeria. However, particularly in Imo State, a number of empirical studies on cassava production have focused more on economic analysis (Nwaiwu, Odii, Ohajianya, Eze, Oguoma, Ibekwe, Henri-Ukoha, Kadiri, Amaechi and Ogun, 2010 and Obasi et al., 2015), production constraint (Chidiebere-Mark, Nwosu, Nwankwo, C. Chikezie, Oduofor and Ejike, 2014 and Henri-Ukoha, Anaeto, Chikezie, Ibeagwa, Ukoha, Oshaji and Anyiam 2015), participation and level of adoption of cassava technologies (Onyemauwa, 2012 and Nnadi, Chikaire, Umunnakwe and Ihenacho, 2013). Similarly, other studies (Ibekwe, Orebiyi, Henri-Ukoha, Okorji, Nwagbo and ChidiebereMark, 2012) that attempted to estimate the relative efficiencies of cassava farmers in Imo State, used the ordinary least squares (OLS) estimation techniques. The use of the ordinary least squares (OLS) estimating technique makes it difficult to determine farm level efficiency as it provides only an average function (Ohajianya, Mgbada, Onu, Enyia, Henri-Ukoha, Ben-Chendo and Godson-Ibeji, 2013) though it provides consistent estimates of the parameters except the intercept (Ogunyinka et al., 2014). To overcome this shortcoming of the OLS, the stochastic frontier function was developed and has been used by several researchers (Onumadu et al., 2014; Ogunniyi, Bifarin and Omoniyi, 2015; Eze et al., 2015; Adegbite and Adeoye, 2015; Denen et al., 2016; Mohammed and Isgin, 2016; Wudineh and Geta, 2016) to estimate efficiency of agricultural production. Its beauty lies in its ability to test and quantify the inefficiency of individual farmers in a sample because it allows for statistical noise rather than attributing all deviation to efficiency difference (Ogunniyi, 2015; Abdul-Hanan and Abdul-Rahaman, 2017). It is also straight forward to implement and interpret (Riatania et al., 2014 and Ettah and Nweze, 2016). A situation that is not possible with other partial measures of efficiency such as the OLS (Okoye et al., 2016). Furthermore, little or no study have rigorously estimated the relative efficiencies (technical, allocative and economic) of resources use of cassava farmers in Imo State, Nigeria. Only the studies of Onumadu et al., (2014) attempted to estimate the concept of resource use efficiencies but his study failed to focus specifically on cassava farmers and in the same vein was conducted in Anambra State which cannot be said to be a true position and representation of Imo State, Nigeria. It is on these backdrops that the study was rigorously undertaken.

\subsection{Methodology}

The study was carried out in Imo State, Nigeria. The State is located in the rainforest agro-ecological region of Nigeria and shares common boundaries with Abia State on the east and northeast, Rivers State on the south, and Anambra State on the west and northwest (Imo State Agricultural Development Project (Imo-ADP, 2013). The State lies between Latitudes $5^{\circ} 45^{1}$ and $6^{\circ} 35^{1}$ North of the equator and Longitudes $6^{\circ} 35^{1}$ and $7^{\circ} 28^{1}$ East of the Greenwich Meridian (Chineke et al., 2011). It occupies the area between the lower River Niger and the upper and middle Imo River (Imo-ADP, 2013). It is bounded on the east by Abia State, on the west by the River Niger and Delta State and on the north by Anambra State, while Rivers State lies to the south (Imo State Ministry of Land and Survey and Urban Planning, 2013). Imo State covers an area of about $5,067.20 \mathrm{~km}^{2}$, with a population of 3,934,899 persons with many subsisting farmers (Nigeria Population Commission (NPC), 2006 and National Bureau of Statistics (NBS), 2007) and population density of about $725 \mathrm{~km}^{2}$ (Imo-ADP, 2015). The State has an average annual temperature of $28^{\circ} \mathrm{C}$, an average annual relative humidity of $80 \%$, average annual rainfall of 1800 to $2500 \mathrm{~mm}$ and an altitude of about $100 \mathrm{~m}$ above sea level (Imo-ADP, 2013).

The State has three agricultural zones namely Orlu, Owerri, and Okigwe agricultural zones. Farming is the main occupation of the rural dwellers in the State. The farmers produce both root and tuber crops of which cassava are predominant. The sample for the study was drawn from cassava farmers in the study area. A multi-stage random sampling technique was adopted in the selection of respondents for the study. Firstly, three Local Government 
Areas (LGAs) were randomly selected from each of the agricultural zone (Orlu, Owerri and Okigwe) in Imo State. The three (3) LGAs selected from Orlu agricultural zone of the State were Njaba, Orlu and Ideato-North. Similarly, the three (3) LGAs selected from Owerri agricultural zone of the State included Ikeduru, Mbaitoli and Owerri North. In the same vein, Ihitte-Uboma, Onuimo and Ehime Mbano were the three (3) LGAs selected from Okigwe agricultural zone. Furthermore, three (3) communities were randomly selected from each of the sampled LGAs, selected from each of the three (3) agricultural zone of the State (Orlu, Owerri and Okigwe) to give a total number of twenty-seven (27) communities each from the area. Finally, four (4) households the three (3) LGAs selected from Owerri agricultural zone cassava farmers were randomly selected from each of the twenty-seven (27) communities to give a total sample size of one-hundred and eight (108) cassava farmers for the study. Ultimately, from the retrieved questionnaires, only ninety (90) individual responses were found useful. The list of cassava farmers in the communities, which forms the sample frame, was obtained from the zonal extension agents of Imo State Agricultural Development Programme (Imo-ADP) in the study area. Primary data was used for the study. Primary data was collected through the use of structured questionnaire and it was supplemented with oral interview in places where the respondents could neither read nor write. Descriptive statistics such as frequency distribution, percentages, mean and flow charts were used analyze the data so as to realize objectives. The objectives were modelled using the stochastic frontier production function. The implicit form of the stochastic frontier production model is specified as follows;

$$
\operatorname{LnY} i j=\beta o+\beta 1 \operatorname{Ln} X 1+\beta 2 \operatorname{Ln} X 2+\beta 3 \operatorname{Ln} X 3+\beta 4 \operatorname{Ln} X 4+\beta 5 \operatorname{Ln} X 5+\beta 6 \operatorname{Ln} X 6
$$

Where;

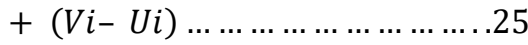

$\mathrm{Y}_{\mathrm{i}}=$ Cassava output $(\mathrm{kg})$

$\mathrm{X}_{1}=$ Farm size (Hectares)

$\mathrm{X}_{2}=$ Labour used (man days)

$\mathrm{X}_{3}=$ Fertilizer $(\mathrm{N})$

$\mathrm{X}_{4}=$ Equipments $(\mathrm{N})$

$\mathrm{X}_{5}=$ Cassava stem cuttings used $(\mathrm{N})$

$\mathrm{L}_{\mathrm{n}}=$ logarithm to base-e

$\mathrm{ij}=\mathrm{j}^{\text {th }}$ observation of the $\mathrm{i}^{\text {th }}$ farmer

$\mathrm{V}_{\mathrm{i}}=$ Is a two-sided, normally distributed random error

$\mathrm{U}_{\mathrm{i}}=$ Is a one-sided efficiency component with a half-normal distribution

\subsection{Maximum Likelihood Estimates of Stochastic Frontier Production Model}

The results of estimates of production and cost functions are presented in table 1 . The estimate of the parameters of the stochastic frontier production model reveals that all the estimated coefficients of the variables of the production function were positive except for that of fertilizer and equipment. The two significant variables are farm size and cassava stem cuttings which were statistically significant at $1 \%$ and $5 \%$ level respectively. The estimate of sigma square $\left(\sigma^{2}\right)$ of 419.52 was statistically significant at $5 \%$ level and therefore, assures us of the goodness of fit and correctness of the distributional assumptions of the composite error. The estimated gamma parameter $(\gamma)$ of 0.827 indicates that $82.7 \%$ of the total variation in cassava output was due to differences in their technical inefficiency. It also gives an indication that the unexplained variations in output are the major sources of random errors. It also confirms the presence of the one-sided error component in the model and hence, the use of the Ordinary Least Square (OLS) in estimating the function, becomes inadequate in representing the data. The Return to Scale (RtS) was 0.549 , which indicates a positive but decreasing return to scale. The findings shows that the farmers were operating at the stage II of the production function, hence, resources and production could be efficient at this stage. The generalized likelihood test gave a value of -915.53 which indicates that the farmers are not fully technically efficient. The findings shares view with the studies of Aboki et al., (2013); Girei et al., (2014); Ogunniyi, (2015); Obike et al., (2016) and Nwike et al., (2017) who reported the technical inefficiencies of cassava farmers at various household levels. Similarly, the result of the stochastic frontier cost function in table 4.13 reveals that all the independent variables gave a positive coefficient. The result implies that as these factors increased, total production cost increased ceteris paribus. The significant variables are depreciation on farmland, cost of cassava stem cuttings, cost of labour and output which were statistically significant at $10 \%, 1 \%, 5 \%$ and $5 \%$ respectively. The gamma $(\gamma)$ estimate was 0.914 and was significant at $1 \%$ level indicating that $91.5 \%$ of the variations in output were caused by economic inefficiency. The sigma square $\left(\delta^{2}\right)$ was 4.312 and was significant at $1 \%$ level, and indicated the goodness of fit and correctness of the specified assumptions of the distribution of the compound error term. The generalized likelihood test gave a value of -3311.561 which indicates that the farmers are not fully economically efficient.

Furthermore, the inefficiency result is presented in table 4.13. The educational level had a positive coefficient with efficiency of the cassava farmers; hence it is statistically significant at $1 \%$ level of probability. This implies that increase in year of formal education leads to decrease in inefficiency of the farmers. It means that farmers 
with higher years of education are in a better position to be more technically efficient than their counterparts. It is very possible that farmers with higher level of education respond easily to the use of improved technology, such as the application of fertilizers, use of pesticides, herbicides and so on thus assisting the farmers to produce close to the frontier. This finding is in conformity with the finding of Ogunniyil et al., (2012) and Tanko and Jirgi (2008) who reported a positive relationship between education and technical efficiency. This shows that education is an important factor that reduces inefficiency among cassava farmers in the study area. This finding supports the study of Emokaro and Oyoboh (2016) who opined that higher level of education determines the quality of skill of farmers, their allocative abilities, efficiency and how well informed they are about the innovations and technologies around them. It also supports the result of Simpa et al., (2014) who reported that farmers with higher educational attainment are usually faster in adoption of improved farming technologies and marketing technique than farmers with little or no education. The membership of cooperative had a positive coefficient with efficiency of the cassava farmers and it was statistically significant at $1 \%$ level of probability. This implies that cassava farmers who belong to cooperative society gather more information, exchange labour, acquire reasonable amount of credit and knowledge on how to efficiently use production resource to enhance their output than those who do not belong to any agricultural cooperative society. Membership of cooperative gives farmers easy access to farm credit, share information, ideals and project a collective demand (Tijjani and Bakari, 2014). Similarly, the studies of Aboki et al., (2013) and Idris et al., (2013) opined that membership of cooperative was positive and significantly related to relative efficiency of farmers. The finding is supported by the result of Berhan (2016) who argued that the more active the farmers are in their involvement in the farmer association, the more information of farm activities carried out and agricultural input distribution they have compared to those who do not join the association. The extension contact was found to be positively related to the efficiency of the cassava farmers. This implies that farmers who received more visit and/or in frequent contact with extension staff/agents are in a better position of being technically efficient in the use of production resources to enhance their agricultural production than those who receive little or no visit. The relationship is significant at $1 \%$ level of probability. The study of Nwaiwu et al., (2015) argued that extension contact enhance farmers production and promote their knowledge on modern farming methods. The findings of Ochi et al., (2016) showed extension contact was positive and significantly related to relative efficiency of cassava farmers. Household size had a negative coefficient with the inefficiency of the cassava farmers. This implies that farmers with larger household size were more technically efficient than smaller household size. The implication of the negative coefficient of household size is that it contributes to resource use efficiency in cassava production in the study area. The effect of household size on farm level resource use efficiency is traceable to its use as a source of labour supply for work on the farm. In some instances family labour may be forced resulting in drudgery and poor workmanship. This relationship is significant at the $1 \%$ level of probability. This findings support the result of Simpa et al., (2014) who reported that large household size is a proxy to labour availability, ensure ease allocation of resources and reduce the cost of hired labour. Farming experience had a positive coefficient with the inefficiency of the cassava farmers and hence it is statistically significant at $1 \%$ level of probability. This implies that increase in year of farming experience leads to increase in efficiency of the farmers. This implies that the more experienced cassava farmers know the problems involved in cassava production and are in a better position to overcome them and improve on their yield than those that had little or no experience. The studies of Ochi et al., (2016) and Berhan (2016) asserted that farming experience is positively and significantly related with efficiency of farmers. This implies that increase in year of farming experience leads to decrease in inefficiency of the farmers. Similarly, The findings is also in line with the study of Akhilomen et al., (2015) who reported that farmers with more years of farming experience would be more efficient, have better knowledge of climatic conditions, better knowledge of efficient allocation of resources and market situation and are thus, expected to run a more efficient and profitable enterprise. 
Table 1. Maximum Likelihood Estimate of Stochastic Frontier Models

\begin{tabular}{|c|c|c|c|c|c|c|c|}
\hline $\begin{array}{l}\text { Production } \\
\text { function } \\
\text { variables } \\
\end{array}$ & Parameters & Coefficient & t-value & $\begin{array}{l}\text { Cost function } \\
\text { variables }\end{array}$ & Parameters & Coefficient & t-value \\
\hline Constant & $\beta_{0}$ & 35.249 & $6.842 * * *$ & Constant & $\beta_{0}$ & -437.528 & $7.610 * * *$ \\
\hline Land & $\beta_{1}$ & 0.372 & $5.092 * * *$ & $\begin{array}{l}\text { Depreciation on } \\
\text { Land }\end{array}$ & $\beta_{1}$ & 0.311 & $1.992 *$ \\
\hline $\begin{array}{l}\text { Cassava stem } \\
\text { Cutting }\end{array}$ & $\beta_{2}$ & 0.215 & $3.575 * *$ & $\begin{array}{l}\text { Cost of Cassava } \\
\text { stem Cutting }\end{array}$ & $\beta_{2}$ & 1.302 & $6.201 * * *$ \\
\hline Labour & $\beta_{3}$ & 0.017 & 0.025 & Cost of Labour & $\beta_{3}$ & 0.085 & $2.405^{* *}$ \\
\hline Fertilizer & $\beta_{4}$ & -0.024 & -0.310 & Cost of Fertilizer & $\beta_{4}$ & 0.115 & 0.050 \\
\hline Equipments & $\beta_{5}$ & -0.031 & -0.550 & $\begin{array}{l}\text { Cost of } \\
\text { Equipments }\end{array}$ & $\beta_{5}$ & 0.273 & 1.005 \\
\hline $\begin{array}{l}\text { Inefficiency } \\
\text { Factor }\end{array}$ & & & & Output & $\mathrm{Y}$ & 188.842 & $3.957 * *$ \\
\hline Education & $\mathrm{Z}_{1}$ & 0.381 & $4.203 * * *$ & Sigma - square & $\sigma^{2}$ & 472.532 & $4.312 * *$ \\
\hline $\begin{array}{l}\text { Membership of } \\
\text { cooperative }\end{array}$ & $\mathrm{Z}_{2}$ & 0.262 & $3.271 * * *$ & Gamma & $\gamma$ & 0.914 & $5.853 * * *$ \\
\hline $\begin{array}{l}\text { Extension } \\
\text { contact }\end{array}$ & $\mathrm{Z}_{3}$ & 0.201 & $3.191 * * * *$ & $\begin{array}{l}\text { Log - Likelihood } \\
\text { function }\end{array}$ & $L(\theta)$ & -3311.561 & \\
\hline Household size & $\mathrm{Z}_{4}$ & -0.305 & $-4.111 * * *$ & & & & \\
\hline $\begin{array}{l}\text { Farming } \\
\text { experiences }\end{array}$ & $\mathrm{Z}_{5}$ & 0.227 & $3.010 * * *$ & & & & \\
\hline Sigma - square & $\sigma^{2}$ & 419.52 & $4.026^{* * *}$ & & & & \\
\hline Gamma & $\Gamma$ & 0.827 & $10.738 * * *$ & & & & \\
\hline $\begin{array}{l}\text { Log - } \\
\text { Likelihood } \\
\text { function }\end{array}$ & $L(\theta)$ & -915.53 & & & & & \\
\hline Return to Scale & (RtS) & 0.549 & & & & & \\
\hline Sample size & $\mathrm{N}$ & 90.00 & & & & & \\
\hline
\end{tabular}

*Statistically Significant at $10 \% ; * *$ Statistically Significant at $5 \% ; * * *$ Statistically Significant at $1 \%$; Source: Frontier 4.1 (2018)

\subsection{Estimation of Allocative Efficiency of the Cassava Farmers}

The results of estimates of allocative efficiency of the cassava farmers are presented in table 2 . The allocative efficiency analysis of cassava production revealed that there was presence of allocative efficiency effects in cassava production in the study area as confirmed by the gamma value of 0.827 that was significant at $5 \%$ level of probability. The gamma $(\gamma)$ value of 0.827 implies that about $82.7 \%$ variation in the output of cassava farmers was due to differences in their allocative efficiencies. The predicted allocative efficiencies (AE) range between 0.412 and 0.980 while the mean $\mathrm{AE}$ was 0.860 . The result also showed that there is ample opportunity for improvement on the level of allocative efficiency in cassava production in the study area. Similarly, the finding shows that if the average cassava farmer in the area was to achieve the AE level of its most efficient counterpart, then the average farmer could realize about $12.30 \%$ of cost saving [i.e., 1-(98.0/86.0) x100]. A similar calculation for the most allocative inefficient farmer reveals cost saving of approximately 53.00\% [i.e., 1-(41.2/86.0)x100]. Moreover, the frequencies of occurrences of the predicted allocative efficiencies in deciles range indicate that the highest number of farmers have allocative efficiencies between $0.90-0.99$. The sample frequency distribution indicates a clustering of allocative efficiencies in the region 0.90 - 0.99 efficiency ranges, representing $58.89 \%$ of the cassava farmers in the area. This implies that the farmers are fairly allocatively efficient. That is, the farmers are fairly allocatively efficient in producing cassava at a given level of output using the cost minimizing input ratio as approximately $90.66 \%$ of the farmers have AE of 0.70 and above. This implies that the farmers are fairly allocative 
efficient. That is, the farmers are efficient in deriving maximum output from input, given the available resources. The study of Onu and Edon, (2009) and Simpa et al., (2014) reported that training/orientation to the farmers, especially towards the new technology and other farming practices improve allocative efficiency of farmers. The result revealed that farmers in the study area are fairly efficient in producing cassava at a given level of output using the cost minimizing input ratio. The study further revealed ample opportunity that exists for improving the level of allocative efficiency of cassava production in the study area. The results tallies with the studies of Obike et al., (2016) and Nwike et al., (2017) who reported the allocative inefficiencies of cassava farmers in cassava production.

Table 2. Deciles Range of Frequency Distribution of Allocative Efficiency of the Cassava Farmers

\begin{tabular}{lll}
\hline Efficiency Level & Frequency & Percentage (\%) \\
\hline $0.40-0.49$ & 2 & 2.22 \\
$0.50-0.59$ & 1 & 1.11 \\
$0.60-0.69$ & 9 & 10.00 \\
$0.70-0.79$ & 12 & 13.33 \\
$0.80-0.89$ & 20 & 22.22 \\
$0.90-0.99$ & 46 & 55.11 \\
Total & 90.0 & 100.0 \\
Mean & 0.860 & \\
Standard Deviation & 0.026 & \\
Minimum & 0.412 & \\
Maximum & 0.980 & \\
\hline
\end{tabular}

Source: Frontier 4.1 (2018)

\section{Conclusion and Recommendation}

The estimated gamma $(\gamma)$ parameter of stochastic frontier production function showed that about $82.7 \%$ variation in output among cassava farmers in the study area was due to differences in relative efficiency. The result of the study showed that the major factor affecting cassava productions in the study area were educations, membership of cooperative, extension contact, farming experiences and farm size, household size, labour and fertilizer. These factors have positive influence on cassava output. The return to scale (RtS) was 0.549 in the study area. This indicates a positive decreasing return to scale and that cassava production was in stage II of the production region where resources and production were believed to be efficient. The mean allocative efficiency was 0.860 . The policy implication of these findings is that cassava farmers in the study area were efficient in allocating their resources considering their scope of operation and the limited resources.

\section{Recommendation}

These recommendations were made based on the major findings of the study;

(i) Farmers particularly on their own should judiciously pool productive resources together through strengthened and stable cooperative society groups as this would enhance their relative efficiencies in cassava production positively in the area.

(ii) Effective agricultural policies and programmes should focus on granting farmers improved access to farm credit and subsidized inputs as these would enable them increase their production efficiencies positively in the area.

(iii) Government at all levels should identify genuine cassava farmers and grant them access to farmland as these would significantly increase their production efficiencies and standard of living positively in the area.

\section{REFERENCES}

Abba, M.W (2012). Technical Efficiency of Sorghum Production in Hong Local Government Area of Adamawa State, Nigeria; International Research Journal of Applied and Basic Sciences; Vol, 3 (10): Pp; 2032-2038

Abdulai, S., P.K Nkegbe and S.A Donkoh (2013). Technical efficiency of maize production in Northern Ghana. African Journal of Agricultural Research, 8:5251-5259.

Abdul-Hanan, A and A. Abdul-Rahaman (2017). Technical Efficiency of Maize Farmers in Ghana: A Stochastic Frontier Approach; International Journal of Innovation and Scientific Research; Vol. 29 No. 2;. Pp. 110-118

Abdulrahman, G.S, O. Yusuf and A. J. Timothy (2016). Technical Efficiency of Rain-fed Lowland Rice Production in Niger State, Nigeria; Asian Journal of Agricultural Extension, Economics \& Sociology 9(4): Pp: $1-12$

Adegbite, O I.and B. Adeoye (2015). Technical Efficiency of Pineapple Production in Osun State, Nigeria; Journal Agris on-line Papers in Economics and Informatics; Pp;3-12

Adekunle, A. K., C.P Adekunle and J.O.Y Aihonsu (2016). Effect Of Health Condition On Technical Efficiency Of Small-Scale Crop Farmers In Yewa Division Of Ogun State, Nigeria; Nigerian Journal of Agriculture, 
Food and Environment. 12(2): Pp:138-143

Adewuyi, S.A, M.U Agbonlahor and A.T Oke (2013). Technical Efficiency Analysis Of Cassava Farmers In Ogun State, Nigeria; IJAFS Vol. 4. No 14: Pp: 515-522

Agbo, F,U , O. O. Ojo, and V.B. Taru (2013). Resource Use Efficiency among Fadama Crop Farmers in Ibadan/Ibarapa Agricultural Zone of Oyo State, Nigeria: A Stochastic Frontier Approach; Journal of Statistical and Econometric Methods, Vol. 2, No.2,Pp; 29-38

Aigner, D.J. C.A.K Lovell and P. Schmidt (1977). Formulation and Estimation of Stochastic Frontier Production Function, Journal of Econometrics, Vol.6, No2; 21-37

Akanbi, S.O (2014). Analyses Of Profitability And Technical Efficiency Of Culture Fish Production In Kwara And Kogi States Of Nigeria; A Ph.D. thesis submitted to the Department of Agricultural Economics and Farm Management, Faculty of Agriculture, University of Ilorin, Kwara State.

Akerele, E.O, O.I Ambali, A.O Idowu and K.P Oshisanya (2014). Analysis of Technical Efficiency of Poultry (Egg) Farmers in Yewa Division of Ogun State, Nigeria; Proceeding of the $15^{\text {th }}$ Annual National Conference of the Nigerian Association of Agricultural Economist (NAAE); $24^{\text {th }}-27^{\text {nd }}$ February, 2014; Federal University of Technology, Akure, Nigeria; Pp:170-180

Akhilomen, L.O, G. M. Bivan, S. A. Rahman and S. A. Sanni (2015). Economic Efficiency Analysis of Pineapple Production in Edo State, Nigeria: A Stochastic Frontier Production Approach; American Journal of Experimental Agriculture 5(3): 267-280

Akpan, S.B, U. E. Okon, E. N. Jeiyol, K. K. Nkeme, D.E John(2013). Economic Efficiency of Cassava Based Farmers in Southern Wetland Region of Cross River State, Nigeria: A Translog Model Approach; International Journal of Humanities and Social Science Vol. 3 No. 12; Pp: 173-181

Alabi, O.F, O.S Aasa and U.S Yahaya (2014). Allocative efficiency in Striga Resistant Maize Production in Giwa Local Governement Area of Kaduna State; Proceeding of the $15^{\text {th }}$ Annual National Conference of the Nigerian Association of Agricultural Economist (NAAE); 24 ${ }^{\text {th }}-27^{\text {nd }}$ February, 2014; Federal University of Technology, Akure, Nigeria; Pp:170-180

Amos, A. P (2013). Allocative Efficiency of Resource Use by Cassava Farmers in Wamba Local Government Area, Nasarawa State, Nigeria; International Journal of Economic Development Research and Investment, Volume 4, Number 3, Pp;34-43

Anyaegbunam, H.N; B. C. Okoye; J. O. Nwaekpe; M. E. Ejechi and P. N. Ajuka (2016).Technical Efficiency of Small-holder Sweetpotato Farmers in Southeast Agro-ecological Zone of Nigeria; American Journal of Experimental Agriculture 12(1): 1-7

Asante-Poku, A. and F. Angelucci (2013). Analysis of Incentives and Disincentives for Cocoa in Ghana. Technical notes series, MAFAP, FAO, Rome. NEPAD, 2013, African Agriculture, Transformation and Outlook. NEPAD, November 2013.

Asogwa, B.C., J.C Umeh, and S.T. Penda. (2011). Analysis of Economic Efficiency of Nigerian Small-Scale Farmers: A Parametric Frontier Approach. Journal of Economics, 2: 89-98

Ataboh, O.E., J.C Umeh and P.T Tsue (2014). Determinants of Technical Efficiency among Rice Farmers in Kogi State, Nigeria; Journal of Agriculture and Sustainability; Volume 6, Number 1, 2014, Pp; 39-49

Audu, S.I , J.O. Otitolaiye and S.J. Ibitoye (2013). A Stochastic Frontier Approach To Measurement Of Cost Efficiency In Small Scale Cassava Production In Kogi State, Nigeria; European Scientific Journal; Vol.9, No.9; Pp:114-122

Balde, B. S, H. Kobayashi, M. Nohmi, A. Ishida, I. Matsumura, M. Esham and E. Tolno (2014). An Analysis of Technical Efficiency of Mangrove Rice Production in the Guinean Coastal Area. Journal of Agricultural Science, 6(8):1310-1320.

Balde, B. S., H. Kobayashi, M. Nohmi, A. Ishida, I. Matsumura, M. Esham and E. Tolno (2014). An Analysis of Technical Efficiency of Mangrove Rice Production in the Guinean Coastal Area. Journal of Agricultural Science, 6(8):Pp: 1310-1320.

Battese, G.E (1992). Frontier Production Functions and Technical Efficiency: A Survey of Empirical Applications in Agricultural Economics". Journal of Agricultural Economics, Vol:3 No. 7: Pp:185-208.

Battese, G.E. and T. Coelli (1995). A Model for Technical Inefficiency effects in Stochastic frontier production function for panel data, Empirical Economics Vol.38, 387-399

Battese, G.E.S.J Amilik and M.A Gill (1996): An investigation of Technical inefficiency of production of wheat farmers in four Districts of Pakistan. Journal of Agricultural Economics, Vol.47, No.1,37-49.

Berhan, T.H (2015). Determinants of Technical, Allocative and Economic Efficiencies among Onion Producing Farmers in Kobo District, Amhara Region, Ethiopia; Journal of Economics and Sustainable Development; Vol.6, No.3;Pp;8-17

Bifarin, J.O., Alimi, T., Baruwa, O.I., and O.C. Ajewole (2010). Determinants of technical, allocative and economic efficiencies in the plantain (Musa spp.) production industry, Ondo State, Nigeria. Federal College of Agriculture, Ondo State, Nigeria 
Central Bank of Nigeria (CBN), (2016). Report on Micro, Small and Medium Enterprises Development Fund (MSMEDF); assessed online 01-05-2017; https://www.cbn.gov.ng/MSME/

Chang, H., and W. Fang (2011). Off-farm work, technical efficiency and rice production risk in Taiwan. Journal of Agricultural Economics 42: Pp: 269-278

Chidiebere-Mark, N.M , C.S Nwosu , O.O Nwankwo, C. Chikezie ,H.U Oduofor and R.D Ejike (2014). Profitability of cassava based crop farmers in owerri agricultural zone of Imo state, South-East Nigeria; Wudpecker Journal of Agricultural Research; Vol. 3(1), Pp. 010 - 015

Chiona, S. (2011). Technical and allocative efficiency of small-holder maize farmers in Zambia. A thesis submitted to the University of Zambia in partial fulfilment of the requirements of the degree of Master of Science in Agricultural Economics. Zambia.

Chineke, T C, M.E, Idinoba and O.C, Ajayi (2011). Seasonal evapotranspiration signatures under a changing landscape and ecosystem management in Nigeria: Implications for agriculture and food security; Am. J. Sci. Ind. Res., 2(2): Pp; 191-204

Chukwu, A. O. (2013). Farmers' Perception of the Effectiveness of Extension Principles in Extension Delivery in Owerri Agricultural zone, Imo State, Nigeria. Int. J. Appl. Res. Technol. 2(3): 38 - 43.

Chukwu, A.O, J.C Nwaiwu and UN Akwiwu (2016). Assessment of the organizational efficiency of imo state agricultural development programme. Inter J Agri Biosci, 5(6):

Denen, D.D, J B. Ayoola, J. Alakali, P. I. Ater, L. Sanni, M. Ngadi, R. Kok (2016). Technical Efficiency Among Small And Medium Scale Entrepreneurs In High Quality Cassava Flour In Four Geo-Political Zones Of Nigeria; European Journal of Physical and Agricultural Sciences Vol. 4 No. 3, Pp:52-64

Dipeolu, A.O and S.O Akinbode (2016). Technical, Economic and Allocative Efficiencies of Pepper Production in South-West Nigeria: A Stochastic Frontier Approach; Journal of Economics and Rural Development; Vol .17. No.1; Pp:24-33

Djomo, C.R.F. (2015). Analysis of Technical Efficiency and Profitability in Small Scale Rice Production in the West-Region of Cameroon. M.Sc Thesis submitted to the Department of Agricultural Economics, University of Agriculture Markurdi, Nigeria.

Eboh, E.C. (1998). Social and Economic Research: Principles and Methods; Lagos: Academic Publications and Development Resource Ltd

Ejike, R.D, J.I Lemchi, M.N Osuji, N.M Chidiebere-Mark (2016). Food Crop Marketing as a Sustainable Source of Livelihood among Rural Women in Nigeria ; International Journal of Gender and Development Issues (IJGDI), v. 2, n. 4, p. 93-104,

Emokaro, C. O. and D.E Oyoboh (2016). Cost Function Analysis Of Cassava Production Under Taungya Farming System In Edo State, Nigeria; Nigerian Journal of Agriculture, Food and Environment. 12(2):Pp; 27-34

Enimu, S., G.O Edet and U.I Ofem (2016). Profitability Analysis Of Cassava Production In Cross-River State, Nigeria International Research Journal of Human Resources and Social Sciences Vol. 3, Issue 8

Etim, N.A, D. Thompson and C.E Onyenweaka (2013). Measuring efficiency of yam (Diosecrea spp) production among poor farmers in rural Nigeria, Journal of agriculture and food sciences, 1(3), Pp: 42-47.

Ettah, O. I and A.O Angba (2016).Analysis of Cost and Returns among Cassava Farmers in Cross River State, Nigeria; International Journal of Science and Research; Vol. 6.3; Pp; 111-114

Ettah, O. I. and N.J Nweze (2016). Analysis and Determinants of Technical Efficiency among Cassava Farmers in Cross River State, Nigeria; International Journal Of Innovative Research \& Development; Vol. 5; No 10; Pp: 109-113;

Eze, C.C, B. Amanze, and O.O Nwankwo (2012). Resource Use Efficiency in Arable Crop Production Among Smallholder Farmers in Owerri Agricultural Zone of Imo State, Nigeria; J. of Agric. Food System.1(4): Pp; $303-309$.

Eze, C.C, D.O Ohajianya, B.O Ibeagwa, C.C Ojinnaka (2015). Analysis of Economic Efficiency of Fadama and Non-Fadama Crop and Livestock Farmers in Imo State, Nigeria; Proceeding of the $16^{\text {th }}$ Annual National Conference of the Nigerian Association of Agricultural Economist (NAAE); $19^{\text {th }}-22^{\text {nd }}$ October, 2015; Kano State University of Science and Technology; Kano State, Nigeria; Pp:42-45

Farell, M. J (1957). The Measurement of Productive Efficiency. Journal of Royal Society, Series A (General), Part III, 120: 253-290.

Federal Ministry of Agriculture and Rural Development, (FMARD) (2016). The Agriculture Promotion Policy (2016 - 2020); Building on the Successes of the ATA, Closing Key Gaps; Policy and Strategy Document;http://fmard.gov.ng/wp-content/uploads/2016/03/2016-Nigeria-Agric-Sector-PolicyRoadmap_June-15-2016_Final.pdf; assessed online 01-05-2017

Federal Ministry of Finance (FMF) (2017); 2017 - 2019 Medium-Term Expenditure Framework and Fiscal Strategy Paper; accessed online Jan. 20; 2017; Budget Office of the Federation Ministry of Budget \& National Planning Abuja, Nigeria http://Www.Budgetoffice.Gov.Ng/Pdfs/2016/2017$2019 \% 20 \mathrm{mtef} \% 20 \& \% 20 \mathrm{fsp} \% 20$ executive $\% 20$ proposal.pdf 
Food and Agricultural Organisation (2016). Production Crop: Cassava, 2016 date. Food and Agriculture Organization, Rome

Food and Agricultural Organisation (FAO) (2016). Production of Cassava in the world, 2016;. Food and Agriculture Organization, Rome.

Girei, A.A, D. C. Maurice and E. G. Onuk (2016). Empirical Analysis of Allocative Efficiency among Fadama Food Crop Farmers in Adamawa State, Nigeria; American Journal of Experimental Agriculture 11(2): Pp: $1-7$

Girei, A.A., B.R Dire, M. Yuguda and M. Salihu (2014). Analysis of productivity and technical efficiency of cassava production in Ardo-Kola and Gassol Local Government Areas of Taraba State, Nigeria; J. Agric. Forestry and Fisheries. 3(1): Pp; 1-5.

Henri-Ukoha, A; F.C Anaeto, C. Chikezie; O. Ibeagwa, I.I Ukoha , I.O. Oshaji and K.H Anyiam (2015). Analysis of Cassava Value Chain in Ideato South Local Government Area, Imo State, South-East Nigeria; International Journal of Life Sciences Vol. 4. No. 4; Pp. 209-215

Ibekwe, U.C, J. S. Orebiyi, A. Henri-Ukoha, E. C. Okorji, E. C. Nwagbo and N. M. Chidiebere-Mark (2012).Resource Use Efficiency in Cassava Production in South East Nigeria; Asian Journal of Agricultural Extension, Economics \& Sociology 1(1): 16-21,

Ike, P.C., and I. Udeh (2011). Comparative analysis of allocative efficiency in input use by credit and non-credit user small-scale poultry farmers in Delta State, Nigeria. Asian Journal of Agricultural Sciences 3: 481-486.

Imo State Agricultural Development Programme (ADP) (2013). An Assessment Study of the Performance of the National Agricultural Technology Support Project in Imo State with Focus of Farmer Adoption of Technology and their Social Economic Improvements; Pp:1-34.

Imo State Agricultural Development Project (Imo-ADP) (2015). Imo ADP Extension Guide. A Paper Presented at the Imo ADP Pre-seeding; Training Workshop; Cochinta Nig. Ltd. February.

International Institute of Tropical Agriculture (IITA)(2016). Overview of Root and Tuber Crops Potential in Nigeria; http://www.iita.org/overview/cassava; assessed on line on 12-10-2016

Iorlamen, T. (2015). Resource use efficiency of Sesame farmers in Benue State, Unpublished Ph.D. thesis submitted to the Department of Agricultural Economics, University of Nigeria Nsukka

Ismatul, H and A. N Susanto (2013).Economies Of Scale And Allocative Efficiency Of Rice Farming At West Seram Regency, Maluku Province, Indonesia; Assessment Institute for Agricultural Technology of Maluku, Indonesian Agency for Agricultural Research and Development; Asian Economic and Financial Review, 3(5):Pp; 624-634

Kadiri, F. A.; C.C Eze, J.S Orebiyi, J.I Lemchi, D.O Ohajianya and I.U Naidu (2014). Technical Efficiency In Paddy Rice Production In Niger Delta Region Of Nigeria; Global Journal of Agricultural Research Vol.2, No.2, PP. 33-43,

Khan, H and I. Saeed (2011). Measurement of Technical, Allocative and Economic Efficiency of Tomato Farms in Northern Pakistan; International Conference on Management, Economics and Social Sciences;Vol.3 No. 12; Pp;459-468

Laha, A., and P.K. Kuri (2011). Measurement of Allocative Efficiency in Agriculture and its Determinants: Evidence from Rural West Bengal, India. International Journal of Agricultural Research, 6: Pp: 377-388

Lockhart, R. S. (1998), Introduction to Statistics and Data Analysis: For the Behavioral Sciences, Macmillan, p. 78, ISBN 9780716729747.

Lora, F, H. Posthumus and A. Martin (2016). A crop of one's own? Women's experiences of cassava commercialization in Nigeria and Malawi; Journal of Gender, Agriculture and Food Security Vol. 1, Issue 2, $\mathrm{Pp} ; 110-128$,

Lulian, L and T. Stamule (2011). Stochastic Frontier Analysis Of Production Function And Cost Function Estimation Methods. Study Of Efficiency At Industry Level; Management \& Marketing Challenges for the Knowledge Society; Vol. 6, No. 1, Pp: 163-176

Mburu, S, C. Ackello-Ogutu, and R. Mulwa (2014). Analysis of Economic Efficiency and Farm Size: A Case Study of Wheat Farmers in Nakuru District, Kenya; Hindawi Publishing Corporation Economics Research International,; http://dx.doi.org/10.1155/2014/802706

Meeusen, W. and J. Van Den Broeck (1977). Efficiency Estimation from Cobb-Douglas production functions with composed error. International Economics Review, 18(2) 435-444.

Mohamed, A. A and A. AL-Basheer (2012). Economic efficiency of wheat production in Gezira scheme, Sudan; Journal of the Saudi Society of Agricultural Sciences; Vol. 2 No. 11, Pp: 1-5

Mohammed, M. A and T. Isgin (2016).Technical Efficiency of Cassava Production in the Savannah Zone of Northern Ghana: Stochastic Frontier Analysis; Journal of Biology, Agriculture and Healthcare; Vol.6, No.20,; Pp:62-72

Mokgalabone, S. M (2015). Analyzing the Technical and Allocative Efficiency of Small-Scale Maize Farmers In Tzaneen Municipality of Mopani District: A Cobb-Douglas And Logistic Regression Approach; A 
Dissertation submitted in fulfillment of the requirements for the degree of Master of Agricultural Economics; School of Agricultural and Environmental Sciences; University Of Limpopo

Moyib, F. R, J. A Akinwumi and V. Okoruwa (2013). Resource-Use Efficiency of Female-cassava Farmers in Rain- Forest Zone of Ogun State; J. Agric. Biodiversity Res; Vol. 2; No. 2, Pp. 17-23;

National Bureau of Statistics (NBS) (2016). The Nigerian Economy: Past, Present and Future; an analysis of the Nigerian economy. http://ec.europa.eu/economy_finance/explained/economies_of_europe/european_economic_outlook/index_ en.htm; Pp; 1-41; Accessed online 23-02-2016

National Bureau of Statistics (NBS) (2007). National Bureau of Statistics Official Gazette (FGP 71/52007/2,500(OL24): Legal Notice on Publication of the Details of the Breakdown of the National and State Provisional Totals, 2006 Census. www.nigerianstat.gov.ng (accessed 28 February, 2016)

Nigeria Population Commission (NPC) (2006). Nigeria Population Commission, Nigeria Federal Government Initiative of individual head count by gender. Spread, State by State, In :MOFINEWS; (accessed 28 February, 2016).Jan-Feb,2007, 6(3):Nigeria.

Nnadi, F.N., C.D Nnadi, J. Chikaire, P.C Umunnakwe and R.A Ihenacho (2013). Analysis of Rural Cassava Farmers' Participation in the Nigeria Agricultural Insurance Scheme in Imo State, Nigeria; Global Journal of Science Frontier Research Agriculture and Veterinary; Volume 13 Issue 11 Version 1.0; Pp;38-45

Nwaiwu, I, M. Odii, D. Ohajianya, C. Eze, N. Oguoma, C. Ibekwe, A. Henri-Ukoha; F. Kadiri; C. Amaechi; J. Ogun,(2010). Comparative Analysis of the Productivity of Sustainable Cassava Farming Under External and Internal Input Use in Imo State Nigeria, New York Science Journal 3(10):Pp; 12-16.

Nwaneri, C.J. and M.E U Obiah (2016). "Cost-Benefit Analysis as a Criterion for Decision-Making on Public Funding of Projects in the Contemporary Change Budget to Enhance Entrepreneurship in a Globalization Era." Proceedings of the 4th Interdisciplinary International Conference Vol. 4(1), June 29-30.

Nwike, M.C., T.O Okoli, P. Oghenehogagame and C.O.A Ugwumba (2017). Economic Efficiency and Returns to Scale of Cassava Production in Southeast Nigeria. International Journal of Agriculture Innovations and Research Volume 6, Issue 1, 2319-1473

Obasi, P. C., A. Henri-Ukoha, O.N. Anosike; U.C. Ibekwe (2015). Net Returns To Cassava-Based Crop Mixtures In Imo State, Nigeria; European Journal of Agriculture and Forestry Research Vol.3, No.1, pp. 15-21

Obasi, P. C., A.H Ukoha, I.S. Ukewuihe and N.M Chidiebere-Mark (2013). Factors Affecting Agricultural Productivity among Arable Crop Farmers in Imo State, Nigeria. American Journal of Experimental Agriculture, Vol. 3, 2, Pp. 443-449

Obiah, M.E, L.A Duru, E.C Akalonu and C.R Onyenagoro (2016a). "Agricultural Extension as an Imperative Tool for Agripreneurship Development in Nigeria: Insight for Sustainable Development." TLEP International Journal Vol. 1 Issue 7.Pp:23-31

Obiah, M.E.U, A. L. Duru, R.C Onyeagoro, E.C Akalonu and C. R Okonya-Chukwu (2016b). Fostering Entrepreneurship For Food Security And Sustainable Development: The Role Of Agricultural Extension Administrators In Imo State ADP; Journal Of Business, Economy and sustainable Development; Vol. 2. No.5; Pp;1-11

Ochi, J.E, R. M. Sani and F. K. Idefoh (2015). Economic Analysis of Resource Use Efficiency among Small Scale Cassava Farmers in Nasarawa State, Nigeria: Implications for Agricultural Transformation Agenda; International Journal of Research in Agriculture and Forestry; Vol.2, No. 2, Pp: 14-21

Ogunbameru, A. and T.A Okeowo (2013). Resource utilization behaviour of cassava producers in Epe area of Lagos state: Stochastic frontier production function approach; Scholarly J. Agric. Sci. 3(11): Pp: 480-486

Ogunniyi, I.T (2015). Technical, allocative and economic efficiency of cassava producers in Oyo State of Nigeria; Scientia Agriculturae; Vol. 11.No. 2; Pp;53-59

Ogunniyi, I.T., Ajao, A.O., Olapade-Ogunwole F. and Ganiyu M.O (2012). Resource-use Efficiency of Cassava Production in Atakunmosa Local Government Area of Osun State. Prime Journal of Social Science 1(2): $27-$ 30.

Ogunyinka, A,I, J.O Bifarin, L.O Omoniyi (2014). Determinate of production efficiency of cocoyam farmers in Oru West Local Government area of Imo State, Nigeria; Proceeding of the $15^{\text {th }}$ Annual National Conference of the Nigerian Association of Agricultural Economist (NAAE); $24^{\text {th }}-27^{\text {nd }}$ February, 2014; Federal University of Technology, Akure, Nigeria; Pp:170-180

Ohajianya, D.O, J. U. Mgbada, P. N. Onu, C. O. Enyia, A. Henri-Ukoha, N. G. Ben-Chendo and C. C. GodsonIbeji (2013). Technical and Economic Efficiencies in Poultry Production in Imo State, Nigeria; American Journal of Experimental Agriculture 3(4): Pp:927-938

Ohen, S B; D.E Ene and G.E Umeze (2014). Resource Use Efficiency of Cassava farmers in Akwa Ibom State, Nigeria; J. Bio. Agric. and Healthcare; Vol.4, No2 Pp; 126-131

Okoye, B.C, A. Abass, B. Bachwenkizi, G. Asumugha, B. Alenkhe, R. Ranaivoson, Randrianarivelo,R., N. Rabemanantsoa and I. Ralimanana (2016). Differentials in technical efficiency among smallholder cassava 
farmers in Central Madagascar: A Cobb Douglas stochastic frontier production approach; Cogent Economics \& Finance;4:1143345 http://dx.doi.org/10.1080/23322039.2016.1143345

Okoye, F.U (2016). Gender and Resource Use Efficiency In Cocoyam Production In Anambra State, Nigeria; An M.Sc Dissertation Submitted To The Department Of Agricultural Economics University Of Nigeria, Nsukka

Oladeebo, J.O and A.S. Oluwaranti (2014). Profit Efficiency among Cassava Producers: Empirical Evidence from South Western Nigeria; Middle-East Journal of Scientific Research 19 (12):Pp:1566-1572

Oluwatusin, F.M (2011). Measuring Technical efficiency of yam farmers in Nigeria: A Stochastic Parametric Approach, Agricultural Journal, 5(2), Pp: 40-46.

Oni, T.O (2016). Socio-economic determinants and profitability of cassava production in Nigeria; International Journal of Agricultural Economics and Extension; Vol. 4 (4), Pp. 229-249

Onubuogu, G.C and S.A.N.D Chidebelu (2012).Technical Efficiency Evaluation of Market Age and Enterprise Size for Broiler Production in Imo State, Nigeria; Nigeria Agricultural Journal; Vol 43 (2)

Onubuogu, G.C, Esiobu N.S, Nwosu C.S, Okereke C.N (2014). Resource use efficiency of smallholder cassava farmers in Owerri Agricultural zone, Imo State, Nigeria; Scholarly J. Agric. Sci. Vol. 7(8), P.. 142-152

Onubuogu. G. C., Chidebelu, S, A. N. D. and Eboh, E. C. (2013). Enterprise Type, Size and Allocative Efficiency of Broiler Production in Imo State, Nigeria. Int. J. Appl. Res. Technol. 2(6): 10 - 19

Onumadu, F. N, G.N Ekwugha,E.E Osahon (2014). Resource Use Efficiency In Arable Crop Production In Oyi Local Government Area, Anambra State, Nigeria; International Journal Of Scientific \& Technology Research Volume 3, Issue 1,Pp;230-235

Onyemauwa, C, Eze C, Emenyonu A, Osagiri I, Nnadi N, Tasie C (2013) Resource use efficiency and productivity of food crop farmers in Idemili North of Anambra State, Nigeria, Wudpecker Journal of Agricultural Research 2:43-48.

Onyemauwa, C.S (2012). Analysis of Women Participation in Cassava Production and Processing in Imo State, Southeast Nigeria; Journal of Economics and Sustainable Development; Vol.3, No.5; Pp; 23-32

Onyenekwe, S.C and E.C Okorji (2015). Effects of off- farm work on the technical efficiency of rice farmers in Enugu State, Nigeria; Journal of Agricultural Economics and Development Vol. 4(4), Pp. 044-050

Orewa, S.I and O.B Izekor (2012). Technical Efficiency analysis of yam production in Edo State: A stochastic frontier Approach, International Journal of Development and Sustainability. 1(2), Pp:516-526.

Oviasogie, D.I (2011). Productivity of yam based farming system in Edo State, Nigeria, Dissertation of Master thesis, Department of Agricultural Economics, University of Technology, Akure, Nigeria. Retrieved on January 5, 2017 from http://hdl.handle.net/123456789.

Oyewo, I.O, A.O Adepoju, M.O Ojo, E.O Oyewo, G.O Atanda (2016). Land Management Practices on Cassava Production in Akinyele Local Government Area, Oyo State Nigeria; Scientia Agriculturae; Vol.15: No. 1 Pp:329-333

Rahman, S.A (2013): Farm Production Efficiency: The Scale of success in Agriculture, the fourth Inaugural Lecture, Nasarawa State University, Keffi, Nigeria, 4-12.

Ranjan, K. G and A. A Mamun (2016). Youth Employment and Entrepreneurship Scenario in Rural Areas of Bangladesh: A Case of Mohammedpur West Union; Technical Report Institutionalizing CBMS_Bangladesh; PEP Asia-CBMS Network, Philippines; accessed online 21-12-2016; https://www.pep-net.org/sites/pep net.org/files/CBMS/PEP_Mtng/13th/Papers/Mamun_Ranjan_Bangladesh.pdf

Riatania, L., A., Daryanto, M., Tambunan and H., Purwati (2014). Technical, Allocative and Economic Efficiency of Pineapple Production in West Java Province, Indonesia: A DEA Approach; IOSR Journal of Agriculture and Veterinary Science; Volume 7, Issue 6 Pp: 18-23

Rousseau, R. (2012). Basic properties of both percentile rank scores and the I3 indicator. Journal of the American Society for Information Science and Technology, 63(2), 416- 420. doi: 10.1002/asi.21684

Sanzidur, R and B.O. Awerije (2015). Technical and scale efficiency of cassava production system in Delta State, Nigeria: an application of Two-Stage DEA approach; Journal of Agriculture and Rural Development in the Tropics and Subtropics; Vol. 116 No. 1; Pp: 59-69

Shehu, J. F, J .T. Iyortyr, S. I. Mshelia and A. U. Jougur (2010). Determinants of yam production and technical efficiency among farmers in Benue State, Nigeria, Journal of social sciences, 24(2) 43-58.

Sheskin, D. J. (2003), Handbook of Parametric and Nonparametric Statistical Procedures (3rd ed.), CRC Press, p. 10, ISBN 9781420036268 .

Simpa, J.O, J. N Nmadu and A. Okino (2014). Technical Efficiency of Smallholder Cassava Farmers in Selected Local Government Areas In Kogi State, Nigeria; PAT; 10 (1): Pp: 74-92

Suleiman H.R and H. Ibrahim (2014). Relative Economic Efficiency of Mechanized and Non-Mechanize Rice Farmers in Nasarawa State, Nigeria; Journal of Economics and Finance; Vol. 5, No. 2.; Pp: 01-08

Sunday, A.B, O. E. Uwemedimo, J. N. Elizabeth, N. K. Kesit, J. E. Daniel, and I. Akwa (2013)."Economic efficiency of Cassava based farmers in Southern Wetland Region of Cross River State, Nigeria: A translog model approach," International Journal of Humanities and Social Science, vol. 3, Pp: 173-181 
Sunday, B.A, V.P Inimfon and S.J Udoka (2012) "Stochastic Profit Efficiency of Homestead based Cassava Farmers in Southern Nigeria", Asian Journal of Agriculture and Rural Development, Vol. 2, No. 3, Pp: 498 $-505$.

Tanko, L. and D.A Aji (2014). Comparative Analysis of Economic Efficiency of Broiler and Egg Production Enterprises in Niger State, Nigeria; Proceeding of the $15^{\text {th }}$ Annual National Conference of the Nigerian Association of Agricultural Economist (NAAE); $24^{\text {th }}-27^{\text {nd }}$ February, 2014; Federal University of Technology, Akure, Nigeria; Pp:170-180

Tanko, L. and Jirgi, A.J. (2008). Economic Efficiency Among Small holder Arable Crop Farmers in Kebbi State, Nigeria. Continental Journal of Agricultural Economics, 2: 14-22

Toluwase, S.O and K. A. Abdu-raheem (2013). Costs and returns analysis of cassava production in Ekiti State, Nigeria; Scholarly Journal of Agricultural Science Vol. 3(10), pp. 454-457

Ume, I.O, A.O Adepoju, M.O Ojo, E.O Oyewo, G.O Atanda (2016). Stochastic Profit Efficiency of Homestead based Cassava Farmers in Southern Nigeria", Asian Journal of Agriculture and Rural Development, Vol. 2, No. 3, Pp: 498 - 505.

United Nations Industrial Development Organization and Federal Government of Nigeria (UNIDO and FGN) (2016). Nigeria Cassava Master Plan (NCMP). United Nations Industrial Development Organization and Federal Government of Nigeria, 2016; www.NigeriaCassavaMasterPlanPdf; Accessed online; January 5, 2017

Waltman, L and M. Schreiber (2012). On the calculation of percentile-based bibliometric indicators. Retrieved May 4, from http://arxiv.org/abs/1205.0646

Wudineh, G.T and E. Geta (2016). Technical efficiency of smallholder wheat farmers: The case of Welmera district, Central Oromia, Ethiopia; Journal of Development and Agricultural Economics; Vol. 8(2), Pp; 3951

Yahaya, K, M.N Shamsudin, A. Radam, and I. A. Latif (2016). Profit Efficiency Among Paddy Farmers: A CobbDouglas Stochastic Frontier Production Function Analysis; Journal of Asian Scientific Research, 6(4): Pp; $66-75$

Yusuf, O. and W. Nwachukwu (2015). Farmers resource-use efficiency in cowpea (Sample-11 Variety) Production in Niger State, Nigeria; Proceeding of the $16^{\text {th }}$ Annual National Conference of the Nigerian Association of Agricultural Economist (NAAE); $19^{\text {th }}-22^{\text {nd }}$ October, 2015; Kano State University of Science and Technology; Kano State, Nigeria; Pp:42-45

Zahidul, K.M., Backman, S., and J. Sumelius (2011). Technical, Economic and Allocative Efficiency of Microfinance Borrowers and Non- Borrowers: Evidence from Peasant Farming in Bangladesh Department of Economics and Management, Faculty of Agriculture and Forestry, European Journal of Social Sciences: 18, Pp: $361-37$ 